OPEN ACCESS

Edited by:

Thomas J. Buckhout,

Humboldt University of Berlin,

Germany

Reviewed by:

Ferenc Fodor

Eötvös Loránd University, Hungary

Tanja Mimmo,

Free University of Bozen-Bolzano, Italy

${ }^{*}$ Correspondence:

Yuanmei Zuo

zuoym@cau.edu.cn

Specialty section:

This article was submitted to

Plant Nutrition,

a section of the journa

Frontiers in Plant Science

Received: 17 December 2018

Accepted: 25 April 2019

Published: 14 May 2019

Citation:

Dai J, Qiu W, Wang N, Wang T, Nakanishi $\mathrm{H}$ and Zuo Y (2019) From

Leguminosae/Gramineae Intercropping Systems to See

Benefits of Intercropping on Iron Nutrition. Front. Plant Sci. 10:605.

doi: 10.3389/fpls.2019.00605

\section{From Leguminosae/Gramineae Intercropping Systems to See Benefits of Intercropping on Iron Nutrition}

\author{
Jing Dai 1,2, Wei Qiu', Nanqi Wang', Tianqi Wang', Hiromi Nakanishi² and Yuanmei Zuo ${ }^{1 *}$ \\ ' College of Resources and Environmental Sciences, National Academy of Agriculture Green Development, Key Lab of \\ Plant-Soil Interaction, MOE, China Agricultural University, Beijing, China, ${ }^{2}$ Graduate School of Agricultural and Life Sciences, \\ The University of Tokyo, Tokyo, Japan
}

To achieve sustainable development with a growing population while sustaining natural resources, a sustainable intensification of agriculture is necessary. Intercropping is useful for low-input/resource-limited agricultural systems. Iron (Fe) deficiency is a worldwide agricultural problem owing to the low solubility and bioavailability of $\mathrm{Fe}$ in alkaline and calcareous soils. Here, we summarize the effects of intercropping systems on Fe nutrition. Several cases showed that intercropping with graminaceous plants could be used to correct Fe nutrition of Leguminosae such as peanut and soybean or fruits such as Psidium guajava L., Citrus, grape and pear in calcareous soils. Intercropping systems have strong positive effects on the physicochemical and biochemical characteristics of soil and the microbial community due to interspecific differences and interactions in the rhizosphere. Rhizosphere interactions can increase the bioavailability of Fe with the help of phytosiderophores. Enriched microorganisms may also facilitate the Fe nutrition of crops. A peanut/maize intercropping system could help us understand the dynamics in rhizosphere and molecular mechanism. However, the role of microbiome in regulating $\mathrm{Fe}$ acquisition of root and the mechanisms underlying these phenomena in other intercropping system except peanut/maize need further work, which will help better utilize intercropping to increase the efficiency of Fe foraging.

Keywords: iron (Fe), intercropping, rhizosphere, microorganism, exudate 


\section{INTERCROPPING WITH GRAMINACEOUS PLANTS FACILITATES THE IRON NUTRITION OF LEGUMINOSAE OR FRUITS IN CALCAREOUS SOILS}

Intercropping is an ancient agricultural technology that involves planting two or more crop species together. It contributes to sustainable agriculture, with higher production, higher nutrient availability (Li et al., 2014), effective weed management (Weerarathne et al., 2017), and pest control (Lopes et al., 2016) in resource-limited agricultural systems. Intercropping can improve soil quality and soil phytoavailability due to species complementarity (Li et al., 2014; Cong et al., 2015).

Iron is an essential micronutrient for plant growth. However, the solubilizing ability and bioavailability of Fe is very low in alkaline and calcareous soils, which limits plant growth and development (Guerinot and Yi, 1994). The solubility of Fe in soil is decreased with increasing $\mathrm{pH}$ and increasing bicarbonate concentrations, which leads to Fe deficiency in crop production on calcareous soils (Marschner, 2012). Plants have evolved two strategies to take up Fe efficiently in response to Fe deficiency: a reduction-based strategy by non-grasses (Strategy I) and a chelation-based strategy by grasses (Strategy II) (Romheld and Marschner, 1986). Under Fe-limiting conditions, Strategy I plants reinforce the reduction of $\mathrm{Fe}^{3+}$ to $\mathrm{Fe}^{2+}$, which is then transported into the root epidermis by Fe-regulated transporters (Robinson et al., 1999; Vert et al., 2002). In this process, Strategy I plants also release protons and phenolic compounds to enhance the bioavailability of Fe (Guerinot and Yi, 1994; Tsai and Schmidt, 2017). Strategy II plants secrete phytosiderophores that can bind $\mathrm{Fe}^{3+}$ in the rhizosphere. These complexes are then taken up by yellow stripe-like (YSL) family transporters in the roots (Curie et al., 2001; Inoue et al., 2009).

Several reports have described how intercropping systems can improve the Fe nutrition of crops (Table 1), which usually involves intercropping Strategy I plants with graminaceous Strategy II species. With the mutual benefits of intercropping systems, the Fe nutrition of the graminaceous species was also sometimes enhanced.

The peanut/maize intercropping system is often used to investigate interspecies interactions between two species using different Fe uptake strategies. Peanut/maize intercropping can enhance the $\mathrm{Fe}$ nutrition of peanuts in calcareous soils (Zuo et al., 2000, 2004; Inal et al., 2007; Dai et al., 2018). Similarly, soybean/maize intercropping with alternating strips and organic fertilizer can increase the $\mathrm{Fe}$ concentration in soybean (Dragicevic et al., 2015). Although intercropping with four grass species did not increase the Fe concentration in dry bean tissues, the SPAD value was significantly higher (Omondi and Kniss, 2014). After intercropping with 12 or 24 sorghum seedlings, the $\mathrm{Fe}$ concentration in leaves of guava seedlings (Psidium guajava L.) increased by 28.2 and 52.2\% in Maryut soil, respectively (Kamal et al., 2000). On three different calcareous soils, intercropping with purple false brome (Brachypodium distachyon) and barley (Hordeum vulgare) enhanced the Fe and chlorophyll concentrations in olive (Olea europaea) leaves (Cañasveras et al., 2014). Groundcover with grass is a promising way to enhance the $\mathrm{Fe}$ nutrition of fruit trees in orchards. On supplying $\mathrm{Fe}$ sulfate to the soil and sowing a mixture of graminaceous species along with pear (Pyrus communis) trees in orchards, Fe-deficiency chlorosis symptoms were alleviated (Tagliavini et al., 2000). This was also seen in citrus plants (Cesco et al., 2006) and grape (Bavaresco et al., 2010) in the presence of grass cover species. Green garlic (Allium sativum L.) is a non-graminaceous monocot. After intercropping with various amounts of green garlic, the root Fe concentrations of cucumber (Cucumis sativus L.) increased, whereas the shoot Fe concentration decreased (Xiao et al., 2013).

All of these effective cases happened in calcareous and/or alkaline soils. The low Fe bioavailability in calcareous soil is induce by $\mathrm{pH}$-related effects. The bicarbonate in calcareous soil can buffer rhizosphere acidification, but also inhibits the expression of ferric reductase, iron transporters and $\mathrm{H}^{+}$-ATPase genes in Strategy I species such as Arabidopsis, pea, tomato and cucumber while has little effect on Strategy II species owing to their chelation-based strategy (Lucena et al., 2007; Marschner, 2012). Compared with graminaceous, non-graminaceous played as gainers in intercropping system on amending $\mathrm{Fe}$ nutrition. However, not all the graminaceous could correct the Fe nutrition of partners. The leaves of citrus and peanut did not recover from Fe deficiency chlorosis intercropped with ys 3 maize mutant plants, which is unable to release phytosiderophores (Cesco et al., 2006; Xiong et al., 2013a). It seems that a complementary strategy is necessary to increase the Fe nutrition of Strategy I plants in intercropping systems.

\section{EFFECT OF RHIZOSPHERE CHANGE ON IRON ACQUISITION IN LEGUMINOSAE/GRAMINEAE INTERCROPPING SYSTEMS}

The interactions in the rhizosphere affect biogeochemical cycling and nutrient availability, which affect plant growth and tolerance to biotic and abiotic stress (Philippot et al., 2013). The interactions between plant roots and the rhizosphere microbiome are critical for improving plant fitness (Zhalnina et al., 2018). Plant can secret different exudates to rhizosphere affected by environmental factors such as plant growth, nutrient availability and microorganisms (Mimmo et al., 2011), which mediate various aspects of the rhizosphere, including soil nutrient mobilization (Bakker et al., 2018; Canarini et al., 2019). The root exudates including primary metabolites (sugars, amino acids, and organic acids) can shape the rhizosphere microbiome (Badri and Vivanco, 2009). In turn, the associated microorganisms can influence plant health and growth (Huang et al., 2014). The soil microorganisms have a significant effect on nutrient availability for plants in the rhizosphere (Mimmo et al., 2014). The microorganisms can quickly utilize root exudates which affects plant nutrient foraging (Alegria Terrazas et al., 2016). Inoculation with plant growth-promoting rhizobacteria showed 
TABLE 1 | The effects of intercropping systems on the iron (Fe) concentration of plant tissues.

\begin{tabular}{|c|c|c|c|c|c|}
\hline Crop & Intercropped & Tissue & Change & $\begin{array}{l}\text { Experimental } \\
\text { conditions }\end{array}$ & References \\
\hline Psidium guajava L. & Maize/Sorghum & Leaf & Increased & Pot & Kamal et al., 2000 \\
\hline Peanut & Maize & Root, shoot, seed & Increased & Field Pot & $\begin{array}{l}\text { Zuo et al., 2000, 2004; Inal } \\
\text { et al., 2007; Dai et al., } 2018\end{array}$ \\
\hline Phaseolus vulgaris L. & Ryegrass/oat/corn/wheat & Leaf & Not Increased ${ }^{1}$ & Field & Omondi and Kniss, 2014 \\
\hline Cucumis sativus & Allium sativum & $\begin{array}{l}\text { Shoot } \\
\text { Root }\end{array}$ & $\begin{array}{l}\text { Decreased } \\
\text { Increased }\end{array}$ & Pot & Xiao et al., 2013 \\
\hline Olive & Purple false brome/barley & Leaf & Increased & Pot & Cañasveras et al., 2014 \\
\hline Soybean & Maize & grain & Increased & Field & Dragicevic et al., 2015 \\
\hline Maize & soybean & & increased & & \\
\hline Citrus & Barley/Poa pratensis/Festuca rubra & Root leaf & Increased & Hydroponics & Cesco et al., 2006 \\
\hline Grape & Festuca ovina & Leaf & Increased & Field & Bavaresco et al., 2010 \\
\hline Pear & Graminaceous species* & Leaf & \# & Field & Tagliavini et al., 2000 \\
\hline
\end{tabular}

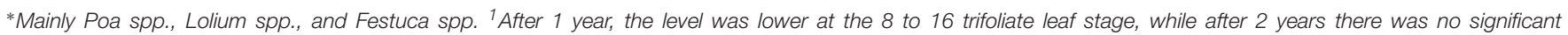

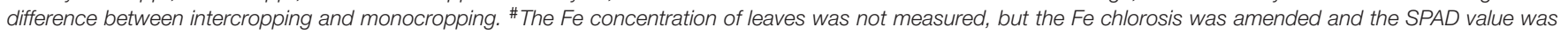
increased in leaves.

potential in benefiting the efficiency of nutrient acquisition of root (Pii et al., 2015).

The effects of intercropping systems on soil physicochemical and biochemical characteristics are complicated due to differences among species (Ladygina and Hedlund, 2010). In typical intercropping systems, legumes benefit soil quality by increasing soil carbon and nitrogen sequestration (Cong et al., 2015; Duchene et al., 2017). In a peanut/maize intercropping system, the available soil nitrogen and phosphorus increased in both the peanut and maize rhizosphere compared with monocropping. Furthermore, the soil urease and phosphomonoesterase activities were also improved by intercropping ( $\mathrm{Li}$ et al., 2016b). Another field experiment showed that the $\mathrm{pH}$ and soil available phosphorus (Olsen-P) concentration in the rhizosphere of peanut crops decreased in the intercropping system after the vegetative stage (Guo et al., 2014). However, in seven cucumber intercropping systems, intercropping had no significant effects on physicochemical characteristics such as soil moisture, $\mathrm{pH}$, and the electrical conductivity in two growing seasons ( $\mathrm{Li}$ and $\mathrm{Wu}, 2018$ ).

Facing Fe-limited conditions, Strategy I and II plants secrete different compounds into the rhizosphere to facilitate Fe uptake (Chen et al., 2017). The phenolic compounds, such as coumarins and flavins, secreted by Strategy I plants not only mobilize insoluble Fe but also affect the root microorganisms to promote plant health (Siso-Terraza et al., 2016; Tsai and Schmidt, 2017; Verbon et al., 2017; Stringlis et al., 2018). Different species can secrete different coumarins to better adapt to their environments (Rajniak et al., 2018). Secondary metabolites secreted from roots including antibiotics and volatiles play a key role in the performance of bacteria (Schulz-Bohm, 2018). However, the directly effect of secondary metabolites on plant nutrient foraging is barely understood. The roots of cereals such as maize secrete a class of defensive metabolites called benzoxazinoids, such as DIMBOA and DIMBOA-Glc (Hu et al., 2018a,b). They not only alter the root-associated microbiota and suppress herbivore performance but also facilitate the Fe uptake of maize.
A recent study in wheat found that heterospecific combinations induced the secretion of DIMBOA (Kong et al., 2018), indicating that intercropping system may promote the secretion of DIMBOA from graminaceous contributing to $\mathrm{Fe}$ availability. The phytosiderophores released by graminaceous species are chelators with high affinity for ferric $\mathrm{Fe}$, and can contribute to the diffusion of Fe in soil (Ma, 2005; Kobayashi and Nishizawa, 2012). The intercropped maize secreted more phytosiderophores in a peanut/maize intercropping system (Xiong et al., 2013a; Dai et al., 2018). The available Fe concentration in the rhizosphere of intercropped peanut was significantly higher than that of monocropped peanut (Guo et al., 2014).

In phosphorus-deficient soil, a maize/common bean intercropping system can efficiently increase the rhizosphere microbial biomass by regulating the $\mathrm{C} / \mathrm{N}$ balance and the $\mathrm{P}$ availability (Latati et al., 2016; Latati et al., 2017). In peanut/maize intercropping systems, better Fe status enhances the expression of the $\mathrm{Fe}^{2+}$ transporter AhDMT1 (Arachis hypogaea divalent metal ion transporter 1) to improve the formation of nodules and nitrogen fixation in peanut roots (Zuo et al., 2004; Shen et al., 2014). Moreover, maize root exudates can increase nodulation and stimulate nitrogen fixation by fava beans (Vicia faba) by promoting flavonoid synthesis in a fava bean/maize intercropping system (Li et al., 2016a). A field experiment showed that peanut/maize intercropping systems increased the abundance of nitrogen-fixing microorganisms, such as Rhizobium hainanense, Rhizobium leguminosarum, and Frankia (Chen et al., 2018). A pot experiment found that peanut/maize intercropping increased not only the abundance of Rhizobium but also Pseudomonas in the peanut rhizosphere (Li et al., 2018). The siderophore pyoverdine secreted by Pseudomonas fluorescens was beneficial to the $\mathrm{Fe}$ nutrition and growth of Arabidopsis in Fe-limited conditions (Trapet et al., 2016). The maize/legumes intercropping systems enriched the soil biodiversity and spores of AMF in the root-zone soil (Punyalue et al., 2018). Intercropping facilitated nitrogen transfer from soybeans to maize on co-inoculation with AMF, as shown by ${ }^{15} \mathrm{~N}$ 
labeling (Wang et al., 2016). AMF application in dill/common bean intercropping systems can enhance the Fe, zinc ( $\mathrm{Zn})$, and manganese $(\mathrm{Mn})$ contents of dill and its competitive ability against weeds (Weisany et al., 2016a,b).

Bacillus subtilis GB03 and Azospirillum brasilense showed a positive effect on $\mathrm{Fe}$ nutrition of Arabidopsis and cucumber, respectively (Zhang et al., 2009; Pii et al., 2015). But about their abundance change in intercropping was rarely reported. How the plants shape their root microbiome and the effect of the specific root exudates under Fe deficiency need to be investigated. The role of microorganisms in the Fe nutrition of plant is also not fully understood. The microorganisms can increase soluble Fe in soil by decreasing soil $\mathrm{pH}$ through nitrification and secreting siderophores, which may be also helpful for the Fe nutrition of plant (Mimmo et al., 2014; Trapet et al., 2016). On another hand, microorganisms are competitive for Fe (Mimmo et al., 2014). In intercropping systems, more attention was paid on the effect of microorganisms on $\mathrm{N}$ and $\mathrm{P}$ turnover. Understanding the difference of effect between graminaceous and non-graminaceous on rhizosphere microbiome and their corresponding function differences can provide a new perspective for explaining the rhizosphere process in intercropping system. Knowing how the rhizosphere facilitates interactions in intercropping systems could help us to optimize plant performance by engineering the plant rhizosphere.

\section{MOLECULAR MECHANISM UNDERLYING THE BENEFICIAL EFFECTS OF INTERCROPPING ON IRON NUTRITION IN PEANUT/MAIZE INTERCROPPING SYSTEM}

Studies of the molecular mechanisms underlying how specific intercropping interactions enhance Fe nutrition only focused on peanut/maize intercropping. In other cases, only the phenomenon was raised. The results of peanut/maize intercropping system can give us a guide to understand the Fe nutrition foraging of Leguminosae/Gramineae intercropping.

Arachis hypogaea iron-regulated transporter 1 (AhIRT1) was the first iron-related transporter to be isolated from the peanut. Ding et al. (2010) found higher AhIRT1 expression during anthesis in intercropped peanut compared with monocropped peanut. In other studies, the expression of AhIRT1 was downregulated in intercropped peanut during the reproductive stage (Xiong et al., 2013a,b; Dai et al., 2018). Further work must examine whether the intercropping interactions have a specific effect on the expression of AhIRT1. The expression of AhFRO1 (Arachis hypogaea ferric reductase oxidase 1), which encodes a $\mathrm{Fe}(\mathrm{III})$-chelate reductase, was affected by the growth stage in intercropping systems. During the vegetative growth of maize, AhFRO1 was upregulated in intercropping systems while peanut was already in reproductive stage. During this period, monocropped peanut did not show Fe deficiency chlorosis. Subsequently, AhFRO1 was downregulated in intercropping systems owing to the better Fe nutrition status. The ferric reductase activity of peanut roots showed a similar tendency, and was higher during the vegetative growth stage and lower during the reproductive growth stage of maize (Guo et al., 2014; Dai et al., 2018). The divalent metal transporter AhNRAMP1 (Arachis hypogaea Natural Resistance-Associated Macrophage Protein 1) is also involved in Fe uptake in peanut (Xiong et al., 2012). Both suppression subtractive hybridization and RT-PCR showed that AhNRAMP1 was upregulated in intercropped peanut during the vegetative stage of maize. In addition, a putative MTP shared similar expression patterns with $A h N R A M P 1$ in an intercropping system (Dai et al., 2018).

The phytosiderophores secreted by maize chelate and solubilize Fe from the rhizosphere, and this is enhanced by specific intercropping interactions (Xiong et al., 2013a; Dai et al., 2018). The enhanced amino acid metabolism may increase the release of phytosiderophores in maize roots. Homocysteine S-methyltransferase (HMT2) and serine acetyltransferase (SAT1) are directly associated with the methionine metabolism pathway. The phytosiderophore-Fe(III) complex can be absorbed across the plasma membrane of roots by the peanut transporter protein AhYSL1 (Arachis hypogaea yellow stripe1-like), a homolog of maize yellow stripe 1 (Xiong et al., 2013a). Several studies have indicated that intercropping also had a positive effect on the expression of AhYSL1, especially during the reproductive stage (Xiong et al., 2013a; Guo et al., 2014; Dai et al., 2018). Further work must examine whether the expression of AhYSL1 is correlated with the phytosiderophores in the rhizosphere. The soil $\mathrm{pH}$ and Olsen-P concentration decreased in reproductive stage under the effect of intercropping, while the available Fe concentration was the highest in rhizosphere (Guo et al., 2014). It seems that beneficial effects differ during the vegetative stage owing to dynamic changes in the rhizosphere. However, how the other factors that can influence Fe bioavailability such as rhizospheric organic compounds and the microbiome changes along with growth phase indicates that it is still an open question. Reproductive stage is a critical period of plant development which associates with sink formation (Marschner, 2012). The more nutrient demands in critical period of maize might drive the more release of phytosiderophores, which might induce the expression of AhYSL1.

Phytosiderophores are a class of Fe chelators that enhance adaption in the natural environment; these commonly exist in grasses, but not exclusively. 2'-Deoxymugineic acid (DMA) was detected in xylem sap from the olive (Olea europaea L.) (Suzuki et al., 2016). As mentioned above, intercropping with purple false brome and barley improved the Fe nutrition of olive trees. However, no study has examined whether the olive can take up DMA-Fe(III) directly, as the peanut can, in an intercropping system (Xiong et al., 2013a). Of course, homologs of the NAAT, aldo-keto reductase (similar to DMAS), and YSL family genes can be found in dicots by checking GenBank, and this is a steppingstone for exploring the evolution of the two Fe uptake strategies. In addition, analyzing the function of phytosiderophores can help us to exploit the application of their analogs in agriculture.

The works in peanut/maize intercropping system can provide a case to understand the molecular mechanism how intercropping system benefits the non-graminaceous 
Fe nutrition. The further research need be taken in other intercropping systems to see if these cases can be $\mathrm{Fe}$ biofortification by intercropping. The driving factors of rhizosphere changes is an important task if one aims at fully understand the biological and ecological mechanism how intercropping system affect Fe turnover.

\section{CONCLUDING REMARKS}

The previous works in intercropping system have provided different insights to uncover the effects and mechanisms of intercropping systems on Fe nutrition. Due to the interspecies facilitation of the rhizosphere, especially between Gramineae and Leguminosae, the intercropping systems show more benefits in resource-limited agricultural system including enhancing Fe nutrition. However, we still do not know how plantmicroorganisms interactions regulate $\mathrm{Fe}$ uptake of root. The microbiome is an essential part to elucidate rhizosphere process in intercropping system. Except peanut/maize intercropping system, whether other Leguminosae/Gramineae intercropping

\section{REFERENCES}

Alegria Terrazas, R., Giles, C., Paterson, E., Robertson-Albertyn, S., Cesco, S., Mimmo, T., et al. (2016). Plant-microbiota interactions as a driver of the mineral turnover in the rhizosphere. Adv. Appl. Microbiol. 95, 1-67. doi: 10. 1016/bs.aambs.2016.03.001

Badri, D. V., and Vivanco, J. M. (2009). Regulation and function of root exudates. Plant Cell Environ. 32, 666-681. doi: 10.1111/j.1365-3040.2008. 01926.x

Bakker, P., Pieterse, C. M. J., de Jonge, R., and Berendsen, R. L. (2018). The soil-borne legacy. Cell 172, 1178-1180. doi: 10.1016/j.cell.2018.02.024

Bavaresco, L., Goncalves, M. I. V. D. B., Civardi, S., Gatti, M., and Ferrari, F. (2010). Effects of traditional and new methods on overcoming lime-induced chlorosis of grapevine. Am. J. Enol. Vitic. 61, 186-190.

Canarini, A., Kaiser, C., Merchant, A., Richter, A., and Wanek, W. (2019). Root exudation of primary metabolites: mechanisms and their roles in plant responses to environmental stimuli. Front. Plant Sci. 10:157. doi: 10.3389/fpls. 2019.00157

Cañasveras, J. C., del Campillo, M. C., Barron, V., and Torrent, J. (2014). Intercropping with grasses helps to reduce iron chlorosis in olive. J. Soil Sci. Plant Nut.14, 554-564.

Cesco, S., Rombola, A. D., Tagliavini, M., Varanini, Z., and Pinton, R. (2006). Phytosiderophores released by graminaceous species promote $\mathrm{Fe}$-59-uptake in citrus. Plant Soil 287, 223-233. doi: 10.1007/s11104-006-9069-4

Chen, J., Arafat, Y., Wu, L. K., Xiao, Z. G., Li, Q. S., Khan, M. A., et al. (2018). Shifts in soil microbial community, soil enzymes and crop yield under peanut/maize intercropping with reduced nitrogen levels. Appl. Soil Ecol. 124, 327-334. doi: 10.1016/j.apsoil.2017.11.010

Chen, Y. T., Wang, Y., and Yeh, K. C. (2017). Role of root exudates in metal acquisition and tolerance. Curr. Opin. Plant Biol. 39, 66-72. doi: 10.1016/j.pbi. 2017.06.004

Cong, W. F., Hoffland, E., Li, L., Six, J., Sun, J. H., Bao, X. G., et al. (2015). Intercropping enhances soil carbon and nitrogen. Glob. Chang Biol. 21, 1715-1726. doi: $10.1111 /$ gcb.12738

Curie, C., Panaviene, Z., Loulergue, C., Dellaporta, S. L., Briat, J. F., and Walker, E. L. (2001). Maize yellow stripel encodes a membrane protein directly involved in Fe(III) uptake. Nature 409, 346-349. doi: 10.1038/35053080

Dai, J., Qiu, W., Wang, N., Nakanishi, H., and Zuo, Y. (2018). Comparative transcriptomic analysis of the roots of intercropped peanut and maize reveals novel insights into peanut iron nutrition. Plant Physiol. Biochem. 127, 516-524. doi: 10.1016/j.plaphy.2018.04.024 systems can be a promising technology to facilitate Fe nutrition in calcareous/alkaline soils need be addressed further. Based on the links between molecular biology and field practices, it will contribute to a universal guide on correcting Fe deficiency chlorosis in different crops with low-input.

\section{AUTHOR CONTRIBUTIONS}

JD summarized and wrote the manuscript. WQ, NW, and TW all made suggestions. HN and YZ revised the manuscript. $\mathrm{YZ}$ provided funding for this work as corresponding author.

\section{FUNDING}

This study was supported by a grant from National Natural Science Foundation of China (NSFC, Grant No. 31872183), the National Key Research and Development Program of China (2017YFD0202102, 2016YFD0200405, and 2016YFE0101100), and the China Scholarship Council.

Ding, H., Duan, L., Li, J., Yan, H., Zhao, M., Zhang, F., et al. (2010). Cloning and functional analysis of the peanut iron transporter AhIRT1 during iron deficiency stress and intercropping with maize. J. Plant Physiol. 167, 996-1002. doi: 10.1016/j.jplph.2009.12.019

Dragicevic, V., Oljaca, S., Stojiljkovic, M., Simic, M., Dolijanovic, Z., and Kravic, N. (2015). Effect of the maize-soybean intercropping system on the potential bioavailability of magnesium, iron and zinc. Crop Pasture Sci. 66, 1118-1127. doi: $10.1071 / \mathrm{Cp} 14211$

Duchene, O., Vian, J. F., and Celette, F. (2017). Intercropping with legume for agroecological cropping systems: complementarity and facilitation processes and the importance of soil microorganisms. A review. Agric. Ecosyst. Environ. 240, 148-161. doi: 10.1016/j.agee.2017.02.019

Guerinot, M. L., and Yi, Y. (1994). Iron: nutritious, noxious, and not readily available. Plant Physiol. 104, 815-820.

Guo, X., Xiong, H., Shen, H., Qiu, W., Ji, C., Zhang, Z., et al. (2014). Dynamics in the rhizosphere and iron-uptake gene expression in peanut induced by intercropping with maize: role in improving iron nutrition in peanut. Plant Physiol. Biochem. 76, 36-43. doi: 10.1016/j.plaphy.2013.12.019

Hu, L., Mateo, P., Ye, M., Zhang, X., Berset, J. D., Handrick, V., et al. (2018a). Plant iron acquisition strategy exploited by an insect herbivore. Science 361, 694-697. doi: $10.1126 /$ science.aat 4082

Hu, L., Robert, C. A. M., Cadot, S., Zhang, X., Ye, M., Li, B., et al. (2018b). Root exudate metabolites drive plant-soil feedbacks on growth and defense by shaping the rhizosphere microbiota. Nat. Commun. 9:2738. doi: 10.1038/ s41467-018-05122-7

Huang, X. F., Chaparro, J. M., Reardon, K. F., Zhang, R. F., Shen, Q. R., and Vivanco, J. M. (2014). Rhizosphere interactions: root exudates, microbes, and microbial communities. Botany 92, 267-275. doi: 10.1139/cjb-2013-0225

Inal, A., Gunes, A., Zhang, F., and Cakmak, I. (2007). Peanut/maize intercropping induced changes in rhizosphere and nutrient concentrations in shoots. Plant Physiol. Biochem. 45, 350-356. doi: 10.1016/j.plaphy.2007.03.016

Inoue, H., Kobayashi, T., Nozoye, T., Takahashi, M., Kakei, Y., Suzuki, K., et al. (2009). Rice OsYSL15 is an iron-regulated iron(III)-deoxymugineic acid transporter expressed in the roots and is essential for iron uptake in early growth of the seedlings. J. Biol. Chem. 284, 3470-3479. doi: 10.1074/jbc.M806042200

Kamal, K., Hagagg, L., and Awad, F. (2000). Improved Fe and Zn acquisition by guava seedlings grown in calcareous soils intercropped with graminaceous species. J. Plant Nutr. 23, 2071-2080. doi: 10.1080/01904160009382166

Kobayashi, T., and Nishizawa, N. K. (2012). Iron uptake, translocation, and regulation in higher plants. Annu. Rev. Plant Biol. 63, 131-152. doi: 10.1146/ annurev-arplant-042811-105522 
Kong, C. H., Zhang, S. Z., Li, Y. H., Xia, Z. C., Yang, X. F., Meiners, S. J., et al. (2018). Plant neighbor detection and allelochemical response are driven by root-secreted signaling chemicals. Nat. Commun. 9:3867. doi: 10.1038/s41467018-06429-1

Ladygina, N., and Hedlund, K. (2010). Plant species influence microbial diversity and carbon allocation in the rhizosphere. Soil Biol. Biochem. 42, 162-168. doi: 10.1016/j.soilbio.2009.10.009

Latati, M., Aouiche, A., Tellah, S., Laribi, A., Benlahrech, S., Kaci, G., et al. (2017). Intercropping maize and common bean enhances microbial carbon and nitrogen availability in low phosphorus soil under mediterranean conditions. Eur. J. Soil Biol. 80, 9-18. doi: 10.1016/j.ejsobi.2017.03.003

Latati, M., Bargaz, A., Belarbi, B., Lazali, M., Benlahrech, S., Tellah, S., et al. (2016). The intercropping common bean with maize improves the rhizobial efficiency, resource use and grain yield under low phosphorus availability. Eur. J. Agron. 72, 80-90. doi: 10.1016/j.eja.2015.09.015

Li, B., Li, Y. Y., Wu, H. M., Zhang, F. F., Li, C. J., Li, X. X., et al. (2016a). Root exudates drive interspecific facilitation by enhancing nodulation and N2 fixation. Proc. Natl. Acad. Sci. U.S.A. 113, 6496-6501. doi: 10.1073/pnas. 1523580113

Li, Q. S., Wu, L. K., Chen, J., Khan, M. A., Luo, X. M., and Lin, W. X. (2016b). Biochemical and microbial properties of rhizospheres under maize/ peanut intercropping. J. Int. Agric. 15, 101-110. doi: 10.1016/S2095-3119(15) 61089-9

Li, L., Tilman, D., Lambers, H., and Zhang, F. S. (2014). Plant diversity and overyielding: insights from belowground facilitation of intercropping in agriculture. New Phytol. 203, 63-69. doi: 10.1111/nph.12778

Li, Q., Chen, J., Wu, L., Luo, X., Li, N., Arafat, Y., et al. (2018). Belowground interactions impact the soil bacterial community, soil fertility, and crop yield in maize/peanut intercropping systems. Int. J. Mol. Sci. 19:622. doi: 10.3390/ ijms 19020622

Li, S., and Wu, F. (2018). Diversity and co-occurrence patterns of soil bacterial and fungal communities in seven intercropping systems. Front. Microbiol. 9:1521. doi: $10.3389 /$ fmicb. 2018.01521

Lopes, T., Hatt, S., Xu, Q., Chen, J., Liu, Y., and Francis, F. (2016). Wheat (Triticum aestivum L.)-based intercropping systems for biological pest control. Pest Manag. Sci. 72, 2193-2202. doi: 10.1002/ps.4332

Lucena, C., Romera, F. J., Rojas, C. L., Garcia, M., Alcantara, E., and Perez-Vicente, R. (2007). Bicarbonate blocks the expression of several genes involved in the physiological responses to Fe deficiency of Strategy I plants. Funct. Plant Biol. 34, 1002-1009. doi: 10.1071/Fp07136

Ma, J. F. (2005). Plant root responses to three abundant soil minerals: silicon, aluminum and iron. Crit. Rev. Plant Sci. 24, 267-281. doi: 10.1080/ 07352680500196017

Marschner, P. (2012). Marschner's Mineral Nutrition of Higher Plants. Cambridge, MA: Academic press.

Mimmo, T., Del Buono, D., Terzano, R., Tomasi, N., Vigani, G., Crecchio, C., et al. (2014). Rhizospheric organic compounds in the soil-microorganism-plant system: their role in iron availability. Eur. J. Soil Sci. 65, 629-642. doi: 10.1111/ ejss. 12158

Mimmo, T., Hann, S., Jaitz, L., Cesco, S., Gessa, C. E., and Puschenreiter, M. (2011). Time and substrate dependent exudation of carboxylates by Lupinus albus L. and Brassica napus L. Plant Physiol. Biochem. 49, 1272-1278. doi: 10.1016/j.plaphy.2011.08.012

Omondi, E. C., and Kniss, A. R. (2014). Interplanting annual ryegrass, wheat, oat, and corn to mitigate iron deficiency in dry beans. PLoS One 9:e115673. doi: 10.1371/journal.pone.0115673

Philippot, L., Raaijmakers, J. M., Lemanceau, P., and van der Putten, W. H. (2013). Going back to the roots: the microbial ecology of the rhizosphere. Nat. Rev. Microbiol. 11, 789-799. doi: 10.1038/nrmicro3109

Pii, Y., Mimmo, T., Tomasi, N., Terzano, R., Cesco, S., and Crecchio, C. (2015). Microbial interactions in the rhizosphere: beneficial influences of plant growth-promoting rhizobacteria on nutrient acquisition process. A review. Biol. Fertil. Soils 51, 403-415. doi: 10.1007/s00374-0150996-1

Punyalue, A., Jamjod, S., and Rerkasem, B. (2018). Intercropping maize with legumes for sustainable highland maize production. Mt. Res. Dev. 38, 35-44. doi: 10.1659/Mrd-Journal-D-17-00048.1

Rajniak, J., Giehl, R. F. H., Chang, E., Murgia, I., von Wiren, N., and Sattely, E. S. (2018). Biosynthesis of redox-active metabolites in response to iron deficiency in plants. Nat. Chem. Biol. 14, 442-450. doi: 10.1038/s41589-0180019-2

Robinson, N. J., Procter, C. M., Connolly, E. L., and Guerinot, M. L. (1999). A ferric-chelate reductase for iron uptake from soils. Nature 397, 694-697. doi: $10.1038 / 17800$

Romheld, V., and Marschner, H. (1986). Evidence for a specific uptake system for iron phytosiderophores in roots of grasses. Plant Physiol. 80, 175-180.

Schulz-Bohm, K. (2018). The Ecological Role of Volatile Mediated Interactions Belowground. Ph.D. thesis, Wageningen University, Wageningen.

Shen, H., Xiong, H., Guo, X., Wang, P., Duan, P., Zhang, L., et al. (2014). AhDMT1, a $\mathrm{Fe}(2+)$ transporter, is involved in improving iron nutrition and N2 fixation in nodules of peanut intercropped with maize in calcareous soils. Planta 239, 1065-1077. doi: 10.1007/s00425-014-2033-2

Siso-Terraza, P., Rios, J. J., Abadia, J., Abadia, A., and Alvarez-Fernandez, A. (2016). Flavins secreted by roots of iron-deficient Beta vulgaris enable mining of ferric oxide via reductive mechanisms. New Phytol. 209, 733-745. doi: 10.1111/ nph.13633

Stringlis, I. A., Yu, K., Feussner, K., de Jonge, R., Van Bentum, S., Van Verk, M. C., et al. (2018). MYB72-dependent coumarin exudation shapes root microbiome assembly to promote plant health. Proc. Natl. Acad. Sci. U.S.A. 115, E5213E5222. doi: 10.1073/pnas.1722335115

Suzuki, M., Nozoye, T., Nagasaka, S., Nakanishi, H., Nishizawa, N. K., and Mori, S. (2016). The detection of endogenous 2'-deoxymugineic acid in olives (Olea europaea L.) indicates the biosynthesis of mugineic acid family phytosiderophores in non-graminaceous plants. Soil Sci. Plant Nutr. 62, 481-488. doi: 10.1080/00380768.2016.1230724

Tagliavini, M., Abadia, J., Rombola, A. D., Abadia, A., Tsipouridis, C., and Marangoni, B. (2000). Agronomic means for the control of iron deficiency chlorosis in deciduous fruit trees. J. Plant Nutr. 23, 2007-2022. doi: 10.1080/ 01904160009382161

Trapet, P., Avoscan, L., Klinguer, A., Pateyron, S., Citerne, S., Chervin, C., et al. (2016). The Pseudomonas fluorescens siderophore pyoverdine weakens arabidopsis thaliana defense in favor of growth in iron-deficient conditions. Plant Physiol. 171, 675-693. doi: 10.1104/pp.15.01537

Tsai, H. H., and Schmidt, W. (2017). Mobilization of iron by plant-borne coumarins. Trends Plant Sci. 22, 538-548. doi: 10.1016/j.tplants.2017.03.008

Verbon, E. H., Trapet, P. L., Stringlis, I. A., Kruijs, S., Bakker, P., and Pieterse, C. M. J. (2017). Iron and immunity. Annu. Rev. Phytopathol. 55, 355-375. doi: 10.1146/annurev-phyto-080516-035537

Vert, G., Grotz, N., Dedaldechamp, F., Gaymard, F., Guerinot, M. L., Briat, J. F., et al. (2002). IRT1, an Arabidopsis transporter essential for iron uptake from the soil and for plant growth. Plant Cell 14, 1223-1233.

Wang, G., Sheng, L., Zhao, D., Sheng, J., Wang, X., and Liao, H. (2016). Allocation of nitrogen and carbon is regulated by nodulation and mycorrhizal networks in soybean/maize intercropping system. Front. Plant Sci. 7:1901. doi: 10.3389/fpls. 2016.01901

Weerarathne, L. V. Y., Marambe, B., and Chauhan, B. S. (2017). Does intercropping play a role in alleviating weeds in cassava as a non-chemical tool of weed management? - A review. Crop Prot. 95, 81-88. doi: 10.1016/j.cropro.2016.08.028

Weisany, W., Raei, Y., Salmasi, S. Z., Sohrabi, Y., and Ghassemi-Golezani, K. (2016a). Arbuscular mycorrhizal fungi induced changes in rhizosphere, essential oil and mineral nutrients uptake in dill/common bean intercropping system. Ann. Appl. Biol. 169, 384-397. doi: 10.1111/aab.12309

Weisany, W., Zehtab-Salmasi, S., Raei, Y., Sohrabi, Y., and Ghassemi-Golezani, K. (2016b). Can arbuscular mycorrhizal fungi improve competitive ability of dill+common bean intercrops against weeds? Eur. J. Agron. 75, 60-71. doi: 10.1016/j.eja.2016.01.006

Xiao, X., Cheng, Z., Meng, H., Liu, L., Li, H., and Dong, Y. (2013). Intercropping of green garlic (Allium sativum L.) induces nutrient concentration changes in the soil and plants in continuously cropped cucumber (Cucumis sativus L.) in a plastic tunnel. PLoS One 8:e62173. doi: 10.1371/journal.pone.0062173

Xiong, H., Kakei, Y., Kobayashi, T., Guo, X., Nakazono, M., Takahashi, H., et al. (2013a). Molecular evidence for phytosiderophore-induced improvement of iron nutrition of peanut intercropped with maize in calcareous soil. Plant Cell Environ. 36, 1888-1902. doi: 10.1111/pce.12097

Xiong, H., Shen, H., Zhang, L., Zhang, Y., Guo, X., Wang, P., et al. (2013b). Comparative proteomic analysis for assessment of the ecological significance of maize and peanut intercropping. J. Proteom. 78, 447-460. doi: 10.1016/j.jprot. 2012.10 .013 
Xiong, H., Kobayashi, T., Kakei, Y., Senoura, T., Nakazono, M., Takahashi, H., et al. (2012). AhNRAMP1 iron transporter is involved in iron acquisition in peanut. J. Exp. Bot. 63, 4437-4446. doi: 10.1093/jxb/ ers117

Zhalnina, K., Louie, K. B., Hao, Z., Mansoori, N., da Rocha, U. N., Shi, S., et al. (2018). Dynamic root exudate chemistry and microbial substrate preferences drive patterns in rhizosphere microbial community assembly. Nat. Microbiol. 3, 470-480. doi: 10.1038/s41564-018-0129-3

Zhang, H., Sun, Y., Xie, X., Kim, M. S., Dowd, S. E., and Paré, P. W. (2009). A soil bacterium regulates plant acquisition of iron via deficiency-inducible mechanisms. Plant J. 58, 568-577. doi: 10.1111/j.1365-313X.2009.03803.x

Zuo, Y. M., Liu, Y. X., Zhang, F. S., and Christie, P. (2004). A study on the improvement iron nutrition of peanut intercropping with maize on nitrogen fixation at early stages of growth of peanut on a calcareous soil. Soil Sci. Plant Nutr. 50, 1071-1078. doi: 10.1080/00380768.2004.10408576
Zuo, Y. M., Zhang, F. S., Li, X. L., and Cao, Y. P. (2000). Studies on the improvement in iron nutrition of peanut by intercropping with maize on a calcareous soil. Plant Soil 220, 13-25. doi: 10.1023/A:100472421 9988

Conflict of Interest Statement: The authors declare that the research was conducted in the absence of any commercial or financial relationships that could be construed as a potential conflict of interest.

Copyright (c) 2019 Dai, Qiu, Wang, Wang, Nakanishi and Zuo. This is an open-access article distributed under the terms of the Creative Commons Attribution License (CC BY). The use, distribution or reproduction in other forums is permitted, provided the original author(s) and the copyright owner(s) are credited and that the original publication in this journal is cited, in accordance with accepted academic practice. No use, distribution or reproduction is permitted which does not comply with these terms. 